\title{
KEWENANGAN NOTARIS DALAM PEMBUATAN SURAT KETERANGAN WARIS UNTUK WARGA NEGARA INDONESIA
}

\author{
I Gusti Kade Prabawa Maha Yoga,Afifah Kusumadara,Endang Sri Kawuryan \\ Program MagisterKenotariatan Fakultas Hukum Universitas Brawijaya \\ Jl. MT. Haryono, Nomor 169. Malang \\ Email:mahayogaprabawa@gmail.com
}

\begin{abstract}
The purpose of this article is to discuss the authority of the notary in making a certificate of inheritance and legal force for the certificate of inheritance for Indonesian citizens after the enactment of Law Number 24 of 2013 concerning Population Administration. The study uses a normative juridical method with a legislative approach and analytical approach. The legislative approach is used to analyze problems caused by inconsistencies in norms of the relevant laws and regulations in making a certificate of inheritance. The analytical approach is used to analyze the meaning contained in the terms used in legislation regarding the drafting of a certificate of inheritance conceptually. Notaries have strong authority in making certificate of inheritance for Indonesian citizens without discriminating between population groups. The certificate of inheritance made by a Notary has perfect legal force.
\end{abstract}

Keywords: Certificate of Inheritance, Notary, Population Classification.

\begin{abstract}
Abstrak: tujuan artikel ini adalah untuk membahas kewenangan notaris dalam membuat surat keterangan waris dan kekuatan hukum surat keterangan waris untuk warga negara Indonesia setelah berlakunya Undang-Undang Nomor 24 Tahun 2013 tentang Administrasi Kependudukan. Kajian menggunakan metode yuridis normatif dengan pendekatan perundang-undangan dan pendekatan analitis. Pendekatan perundang-undangan digunakan untuk menganalisis masalah yang disebabkan oleh inkonsistensi norma dari peraturan perundang-undangan yang terkait dalam pembuatan surat keterangan waris. Pendekatan analitis digunakan untuk menganalisis makna yang terkandung dalam istilah-istilah yang digunakan dalam peraturan perundang-undangan mengenai pembuatan surat keterangan waris secara konsepsional. Notaris memiliki kewenangan yang kuat dalam pembuatan surat keterangan waris untuk warga negara Indonesia tanpa membeda-bedakan golongan penduduk. Surat keterangan waris yang dibuat oleh Notaris memiliki kekuatan hukum yang sempurna.
\end{abstract}

Kata kunci: Surat Keterangan Waris, Notaris, Penggolongan Penduduk

Indonesia dikenal sebagai negara yang bercorak multikultural, multi etnik, agama, ras, dan multi golongan. Sesanti Bhinneka Tunggal Ika secara de facto mencerminkan kemajemukan budaya bangsa dalam naungan negara kesatuan republik Indonesia. Wilayah negara yang membentang luas dari Sabang sampai Merauke, memiliki sumber daya alam (natural resources) yang melimpah bak untaian zamrud di bentang garis katulistiwa, dan juga sumber daya budaya (cultural resources) yang beragam coraknya (Nurjaya, 2008).

Adanya keanekaragaman suku bangsa ini menyebabkan pemerintah kolonial Belanda pada zaman penjajahan menerapkan politik hukum mengenai penggolongan penduduk. Penduduk Indonesia dibagi dalam 3 golongan dan masing-masing golongan penduduk tersebut mempunyai Hukum Perdata sendiri-sendiri. Pada jaman Hindia Belanda, dibidang Hukum Perdata pada umumnya dan Hukum Perdata Waris pada khususnya di jumpai pluralisme hukum. Hal ini terjadi karena pemerintah Hindia Belanda menurut pasal 163 ayat (1) I.S (Indische Staats Regeling), penduduk Indonesia dibagi dalam 3 golongan penduduk yaitu (Simanjutak, 1999):

Golongan Eropa, menurut pasal 163 ayat (2)

I.S, yang termasuk golongan Eropa adalah : 1) 
Semua warga negara Belanda, 2) Orang Eropa, 3) Warga negara Jepang, 4) Orang-orang yang berasal dari negara lain yang hukum kekeluargaannya sama dengan hukum keluarga Belanda, terutama azas monogami, 5) Keturunan mereka yang tersebut di atas.

Golongan Pribumi, menurut pasal 163 ayat (3) I.S, yang termasuk golongan pribumi adalah : 1) Orang Indonesia asli, 2) Mereka yang semula termasuk golongan lain, lalu membaurkan dirinya kedalam orang Indonesia asli. Golongan Timur Asing, menurut pasal 163 ayat (4) I.S, yang termasuk golongan Timur Asing adalah mereka yang tidak termasuk dalam golongan Eropa atau Indonesia asli yaitu : 1) Golongan Timur Asing Tionghoa (Cina) dan 2) Golongan Timur Asing bukan Tionghoa.

Eksistensi pasal 163 I.S berlaku berdasarkan ketentuan dalam Pasal II aturan peralihan UndangUndang Dasar Tahun 1945 (UUD 1945) yang menjelaskan bahwa "Segala badan Negara dan peraturan yang ada masih langsung berlaku, selama belum diadakan yang baru menurut Undang-Undang Dasar ini” (Wahab, 2007).

Pasal 4 Undang-Undang Nomor 12 Tahun 2006 Tentang Kewarganegaraan (selanjutnya disebut sebagai Undang-Undang Kewarganegaraan) pada intinya hanya membedakan penduduk menjadi dua yaitu Warga Negara Indonesia (WNI) dan Warga Negara Asing (WNA), Undang-Undang Kewarganegaraan tidak dapat berdiri sendiri karena diperlukan pengaturan lebih lanjut mengenai penentuan status pribadi dan status hukum setiap peristiwa kependudukan dan peristiwa penting yang di alami oleh seseorang yang tinggal di wilayah Indonesia baik Warga Negara Indonesia (WNI) maupun Warga Negara Asing (WNA) untuk memberikan perlindungan. Sebagai pelengkap Undang-Undang Kewarganegaraan, lahir Undang-Undang Nomor 23 Tahun 2006 sebagaimana diubah dengan Undang-Undang Nomor 24 Tahun 2013 Tentang Administrasi Kependudukan (Selanjutnya disebut sebagai Undang-Undang Administrasi Kependudukan) yang mempertegas penghapusan keberlakuan penggolongan penduduk berdasarkan Staatsblad (STB 1917:129, STB 1924:556 dan STB 1917:12).

Penerapan penggolongan penduduk masih ditemukan pada pembuatan surat keterangan waris. Surat keterangan waris diperlukan dalam proses pendaftaran tanah khususnya karena pewarisan, sebagaimana dijelaskan pada Pasal 42 Ayat (1) yaitu:
"Peralihan hak karena pewarisan terjadi karena hukum pada saat pemegang hak yang bersangkutan meninggal dunia. Dalam arti, bahwa sejak itu para ahli waris menjadi pemegang haknya yang baru. Mengenai siapa yang menjadi ahli waris diatur dalam Hukum Perdata yang berlaku bagi pewaris. Pendaftaran peralihan hak karena pewarisan juga diwajibkan, dalam rangka memberikan perlindungan huum kepada para ahli waris dan demi ketertiban tata usaha pendaftaran tanah, agar data yang tersimpan dan disajikan selalu menunjukkan keadaan yang mutakhir. Surat tanda bukti sebagai ahli waris dapat berupa Akta Keterangan Hak Mewaris, atau Surat Penetapan Ahli Waris atau Surat Keterangan Ahli Waris."

Ketentuan pembuatan surat keterangan waris di Negara Indonesia sampai saat ini masih didasarkan pada pembagian golongan penduduk, sebagaimana dijelaskan dalam Pasal 42 ayat (1) Peraturan Pemerintah No. 24 tahun 1997 tentang Pendaftaran Tanah juncto ketentuan Pasal 111 ayat (1) huruf c Peraturan Kepala Badan Pertanahan Nasional No. 8 Tahun 2012 tentang Perubahan Peraturan Menteri Negara Agraria/ Kepala Badan Pertanahan Nasional Nomor 3 Tahun 1997 tentang Ketentuan Pelaksanaan Peraturan Pemerintah No. 24 Tahun 1997 tentang Pendaftaran Tanah (selanjutnya disebut sebagai Perkaban Nomor 3 Tahun 1997), yang berbunyi :surat tanda bukti sebagai ahli waris yang dapat berupa: 1) wasiat dari pewaris, atau, 2) putusan Pengadilan, atau 3) penetapan hakim/Ketua Pengadilan, atau 4) bagi warganegara Indonesia penduduk asli: surat keterangan ahli waris yang dibuat oleh para ahli waris dengan disaksikan oleh 2 (dua) orang saksi dan dikuatkan oleh Kepala Desa/Kelurahan dan Camat tempat tinggal pewaris pada waktu meninggal dunia; a) bagi warganegara Indonesia keturunan Tionghoa: akta keterangan hak mewaris dari Notaris, b) bagi warganegara Indonesia keturunan Timur Asing lainnya: surat keterangan waris dari Balai Harta Peninggalan: 1) surat kuasa tertulis dari ahli waris apabila yang mengajukan permohonan pendaftaran peralih-an hak bukan ahli waris yang bersangkutan; 2) bukti identitas ahli waris.

Berdasarkan uraian di atas terdapat inkonsistensi norma mengenai pengaturan kewenangan pembuatan surat keterangan waris setelah berlakunya Undang-Undang Administrasi Kependudukan karena dihapuskan dan dicabutnya pengaturan mengenai penggolongan penduduk 
yang di atur pasal 163 ayat (1) I.S (Indische Staats Regeling), Notaris sebagai pejabat yang berwenang membuat alat bukti otentik dimungkinkan memiliki kewenangan yang lebih luas dalam pembuatan surat keterangan waris ditinjau dari perspektif Undang-Undang Administrasi Kependudukan. Pokok permasalahan yang diangkat dalam penelitian ini dibagi menjadi dua permasalahan yaitu : 1 . Bagaimana kewenangan notaris mengenai pembuatan surat keterangan waris untuk warga negara Indonesia dalam perspektif Pasal 106 Undang-Undang Nomor 23 Tahun 2006 Sebagaimana Diubah dengan Undang-Undang Nomor 24 Tahun 2013 Tentang Administrasi Kependudukan?, 2 Bagaimana kekuatan hukum surat keterangan waris untuk warga negara Indonesia yang dibuat oleh notaris dalam perspektif Pasal 106 Undang-Undang Nomor 23 Tahun 2006 Sebagaimana Diubah dengan Undang-Undang Nomor 24 Tahun 2013 Tentang Administrasi Kependudukan?

\section{HASIL DAN PEMBAHASAN}

\section{Kewenangan Notaris Membuat Surat Keterangan Waris Untuk Warga Negara In- donesia Berdasarkan Undang-Undang Nomor 24 Tahun 2013 Tentang Administrasi Kependudukan}

Notaris sebagai pejabat yang diberi kewenangan oleh negara untuk membuat alat bukti dalam bentuk akta otentik, dengan berlakunya Undang-Undang Administrasi Kependudukan Notaris memiliki peran yang sangat penting dalam pembuatan surat keterangan waris, berdasarkan hal tersebut penulis akan membahas kewenangan Notaris mengenai pembuatan surat keterangan waris untuk warga negara Indonesia perspektif Pasal 106 Undang-Undang Nomor 23 Tahun 2006 Sebagaimana Diubah Dengan Undang-Undang Nomor 24 Tahun 2013 Tentang Administrasi Kependudukan dalam penjelasan sebagai berikut:

Surat Keterangan Waris adalah surat yang dijadikan dasar adanya hak bagi pihak ahli waris untuk melakukan perbuatan hukum atas suatu warisan yan ditinggalkan pewaris. Dengan adanya surat keterangan waris maka ahli waris dapat melakukan tindakan hukum terhadap harta peninggalan pewaris secara bersama-sama, baik mengenai tindakan kepengurusan maupun tindakan kepemilikan atas warisan tersebut, dalam hal ini adalah berupa barang-barang harta peninggalan pewaris berupa tanah yang apabila ingin dilakukan balik nama dapat mengajukan permohonan ke Kantor Pertanahan setempat yaitu dengan cara (Harun, 2010): a) Melakukan pendaftaran peralihan hak (balik nama) untuk tanah yang sudah terdaftar (bersertifikat). b)Melakukan permohonan hak baru (sertifikat) atas tanah yang belum terdaftar seperti misalnya tanah girik, tanah bekas hak barat, tanah negara.

Pada tanggal 8 Juni 1997 diundangkan Peraturan Pemerintah Nomor 24 Tahun 1997 tentang Pendaftaran Tanah menggantikan Peraturan Pemerintah Nomor 10 Tahun 1961. Untuk melaksanakan Peraturan Pemerintah Nomor 24 Tahun 1997 ini maka dibuat Peraturan Menteri Negara Agraria/Kepala Badan Pertanahan Nasional Nomor 3 Tahun 1997 tentang Ketentuan Pelaksanaan Peraturan Pemerintah Nomor 24 Tahun 1997 tentang Pendaftaran Tanah. Pasal 42 Peraturan Pemerintah Nomor 24 Tahun 1997 tentang Pendaftaran Tanah memerintahkan adanya surat keterangan waris sebagai dasar peralihan hak karena pewarisan, yang pada intinya bahwa jika penerima waris hanya satu orang, maka pembuktian peralihan haknya adalah surat tanda bukti sebagai ahli waris.

Pembuatan bukti sebagai ahli waris dibuat berdasarkan prinsip penggolongan penduduk yang terdapat dalam ketentuan Pasal 111 ayat (1) huruf c Peraturan Menteri Agraria / Kepala Badan Pertanahan Nasional No.3 Tahun 1997 sebagaimana dirubah dengan Peraturan Kepala Badan Pertanahan Nasional No. 8 Tahun 2012 tentang Ketentuan Pelaksanaan Peraturan Pemerintah No. 24 Tahun 1997 tentang Pendaftaran Tanah. Pihak yang berwenang mengeluarkan penetapan mengenai Pembagian Harta Peninggalan orang yang beragama islam yaitu Pengadilan Agama. Sebagaimana dengan yang diatur dalam Pasal 4 huruf b Undang-Undang Nomor 3 Tahun 2006 tentang perubahan atas Undang-Undang Nomor 7 Tahun 1989 tentang Peradilan Agama Surat keterangan waris yang dalam pembuatannya dibagi menjadi beberapa golongan penduduk ini hanya terkait mengenai pengurusan tanah dikarenakan dasar hukumnya berada pada peraturan mengenai pertanahan.

Namun hal ini dijadikan dasar acuan untuk perbuatan apapun diluar tanah karena memang tidak ada peraturan yang secara spesifik mengatur 
mengenai surat keterangan waris. Indonesia telah membuat peraturan perundang-undangan yang sesuai dengan Pasal 26 ayat (2) Undang-Undang Dasar 1945 dengan prinsip persamaan hak semua warga negara dan penghapusan golongangolongan penduduk sehingga selanjutnya yang ada hanya Warga Negara Indonesia dan Warga Negara Asing yakni Undang-Undang Nomor 12 Tahun 2006 tentang Kewarganegaraan Republik Indonesia dan diikuti oleh Undang-Undang Nomor 23 Tahun 2006 sebagaimana diubah dengan Undang-Undang Nomor 24 Tahun 2013 Tentang Administrasi Kependudukan (Selanjutnya disebut sebagai Undang-Undang Administrasi Kependudukan).

Pasal 106 Undang-Undang Administrasi Kependudukan menjelaskan, pada saat undangundang ini mulai berlaku, aturan-aturan yang disebut dibawah ini yaitu : a) Buku Kesatu Bab Kedua Bagian Kedua dan Bab Ketiga Kitab Undang-Undang Hukum Perdata (Burgerlijk Wetboek voor Indonesie, Staatsblad 1847:23); b) Peraturan Pencatatan Sipil untuk Golongan Eropa (Reglement op het Holden der Registers van den Burgerlijken Stand voor Europeanen, Staatsblad 1849:25 sebagaimana telah diubah terakhir dengan Staatsblad 1946:136); c) Peraturan Pencatatan Sipil untuk Golongan Cina (Bepalingen voor Geheel Indonesie Betreffende het Burgerlijken Handelsrecht van de Chinezean, Staatsblad 1917:129 jo. Staatsblad 1939:288 sebagaimana diubah terakhir dengan Staatsblad 1946:136); d) Peraturan Pencatatan Sipil untuk Golongan Indonesia (Reglement op het Holden van de Registers van den Burgerlijeken Stand voor Eenigle Groepen v.d nit tot de Onderhoringer van een Zelfbestuur, behoorende Ind. Bevolking van Java en Madura,Staatsblad 1920:751 jo. Staatsblad 1927:564); e) Peraturan Pencatatan Sipil untuk Golongan Kristen Indonesia (Huwelijksordonantie voor Christenen Indonesiers Java, Minahasa en Amboiena, Staatsblad 1933:74 jo. Staatsblad 1936:607 sebagaimana diubah terakhir dengan Staatsblad 1939:288); f) Undang-Undang Nomor 4 Tahun 1961 tentang Perubahan atau Penambahan Nama Keluarga (Lembaran Negara Tahun 1961 Nomor 15, Tambahan Lembaran Negara Nomor 2154).

Keberlakuannya dicabut dan dinyatakan tidak berlaku. Berdasarkan pasal diatas, prinsip penggolongan penduduk sejak berlakunya Undang-Undang Administrasi Kependudukan sudah tidak berlaku lagi, khususnya ketentuan Pasal 111 ayat (1) huruf c Peraturan Kepala Badan Pertanahan Nasional Nomor 3 Tahun 1997 sebagaimana diubah dengan Peraturan Kepala Badan Pertanahan Nasional Nomor 8 Tahun 2012 tentang Perubahan Peraturan Menteri Negara Agraria/Kepala Badan Pertanahan Nasional Nomor 3 Tahun 1997 tentang Ketentuan Pelaksanaan Peraturan Pemerintah No. 24 Tahun 1997 tentang Pendaftaran Tanah (Selanjutnya disebut sebagai Perkaban Nomor 3 Tahun 1997).

Dengan kata lain ketentuan pada Pasal 111 ayat (1) huruf c Perkaban Nomor 3 Tahun 1997 bertentangan dengan Pasal 106 Undang-Undang Administrasi Kependudukan, karena terjadi inkonsistensi norma mengenai penghapusan prinsip penggolongan penduduk. Jika dianalisis dengan teori hierarki peraturan perundang-undangan, Berdasarkan teori Nawiasky, A. Hamid S. Attamimi menerapkannya pada struktur tata hukum di Indonesia. Attamimi menunjukkan struktur hierarki tata hukum Indonesia. Berdasarkan teori tersebut, struktur tata hukum Indonesia adalah (Wahab, 2007): 1) Staatsfundamentalnorm: Pancasila (Pembukaan UUD RI tahun 1945). 2) Staatsgrundgesetz: Batang Tubuh UUD 1945, Tap MPR, dan Konvensi Ketatanegaraan. 3) Formell gesetz: Undang-Undang. 4) Verordnung en Autonome Satzung : Secara hierarki mulai dari Peraturan Pemerintah hingga Keputusan Bupati atau Walikota.

Sedangkan dalam Pasal 7 Undang-Undang Nomor 12 tahun 2011 tentang Pembentukan Peraturan Perundangan-undangan, dalam Pasal 7 menyebutkan jenis dan hierarki Peraturan Perundang-undangan terdiri atas: (a) UndangUndang Dasar Negara Republik Indonesia tahun 1945; (b) Ketetapan Majelis Permusyawaratan Rakyat; (c) Undang-Undang/Peraturan Pemerintah Pengganti Undang-Undang; (d) Peraturan Pemerintah; (e) Peraturan Presiden; (f) Peraturan Daerah Provinsi; dan (g) Peraturan Daerah Kabupaten / Kota.

PerkabanNomor 3 Tahun 1997 merupakan aturan pelaksanaan dari Peraturan Pemerintah No. 24 Tahun 1997 tentang Pendaftaran Tanah, berdasarkan ketentuan dalam Pasal 7 diatas, kedudukan Undang-Undang Nomor 23 Tahun 2006 sebagaimana diubah dengan Undang-Undang Nomor 24 Tahun 2013 Tentang Administrasi Kependudukan lebih tinggi daripada Perkaban 
Nomor 3 Tahun 1997, berdasarkan asas Lex superiori derogate legi inferiori berarti aturan hukum yang lebih tinggi kedudukannya akan melumpuhkan peraturan hukum yang memiliki kedudukan lebih rendah (Sudikno, 1986).Sehingga ketentuan Undang-Undang Nomor 23 Tahun 2006 sebagaimana diubah dengan Undang-Undang Nomor 24 Tahun 2013 Tentang Administrasi Kependudukan melumpuhkan atau mengenyampingkan ketentuan Perkaban Nomor 3 Tahun 1997.

Berdasarkan penjelasan diatas, jika dilihat dari perspektif Pasal 106 Undang-Undang Nomor 23 Tahun 2006 sebagaimana diubah dengan Undang-Undang Nomor 24 Tahun 2013 Tentang Administrasi Kependudukan, kewenangan pembuatan surat keterangan waris tidak dibatasi oleh ketentuan Pasal 111 ayat (1) huruf c Perkaban Nomor 3 Tahun 1997, karena penggolongan penduduk sudah tidak diterapkan lagi sejak berlakunya Undang-Undang Administrasi Kependudukan.

Surat keterangan waris adalah suatu bentuk pembuktian dari ahli waris tentang kebenaran bahwa orang yang tepat dan berhak mewaris dari pewaris, yang didalam isinya menerangkan mengenai kedudukan ahli waris dan hubungan dengan pewaris (Hartono, 1991).Terdapat beberapa unsur dalam pewarisan yang penting, yakni pewaris, ahli waris dan warisan. Ahli waris merupakan orang yang berhak atas harta warisan yang ditinggalkan oleh pewarisnya (Kie, 2007). Warisan adalah harta yang ditinggalkan oleh orang yang meninggal, baik berupa aktiva maupun pasiva.

Keterangan hak waris dibuat dengan tujuan untuk membuktikan siapa- siapa yang merupakan ahli waris yang sah atas harta peninggalan yang telah terbuka menurut hukum dan berapa porsi atau bagian masing-masing ahli waris terhadap harta peninggalan yang telah telah terbuka tersebut. Keterangan hak waris disebut juga dengan surat keterangan hak waris (SKHW), surat keterangan waris (SKW) merupakan surat bukti waris yaitu surat yang membuktikan bahwa yang disebutkan di dalam surat keterangan waris tersebut adalah ahli waris dari pewaris tertentu. Keterangan hak waris untuk melakukan balik nama atas barang harta peninggalan yang diterima dan atas nama pewaris menjadi atas nama seluruh ahli waris. Tindakan kepemilikan yang dimaksud misalnyaadalah (Kartasaputra, 2012):
1. Khusus untuk barang-barang harta peninggalkan berupa tanah, maka dapat mengajukan permohonan ke Kantor Pertanahan setempat, yaitu: a) Melakukan pendaftaran peralihan hak (balik nama) untuk tanah yang sudah terdaftar (bersertipikat),dan b) Melakukan permohonan hak baru (sertipikat) atas tanah yang belum terdaftar seperti misalnya tanah girik, tanah bekas hak barat, tanahnegara.

2. Menggadakan atau dengan cara menjaminkan barang-barang harta peninggalkan tersebut kepada pihak lain atau kreditur, apabila ahli waris hendak meminjam uang atau memintakredit.

3. Mengalihkan barang-barang harta peninggalkan tersebut pada pihak lain, misalnya menjual, menghibahkan, melepaskan hak dan lain-lainnya yang sifatnya berupa suatu peralihanhak.

4. Merubah status kepemilikan bersama atas barang harta peninggalan menjadi milik dari masing-masing ahli waris dengan cara melakukan membuat akta pembagian dari pemisahan harta peninggalan dihadapan Notaris.

Surat Keterangan Waris seringkali digunakan pada pelaksanaan pendaftaran peralihan hak atas tanah karena pewarisan, pada penjelasan pasal 42 Ayat (1) Peraturan Pemerintah No. 24 Tahun 1997 tentang Pendaftaran Tanah dijelaskan,

Peralihan hak karena pewarisan terjadi karena hukum pada saat pemegang hak yang bersangkutan meninggal dunia. Dalam arti, bahwa sejak itu para ahli waris menjadi pemegang haknya yang baru. Mengenai siapa yang menjadi ahli waris diatur dalam Hukum Perdata yang berlaku bagi pewaris. Pendaftaran peralihan hak karena pewarisan juga diwajibkan, dalam rangka memberikan perlindungan huum kepada para ahli waris dan demi ketertiban tata usaha pendaftaran tanah, agar data yang tersimpan dan disajikan selalu menunjukkan keadaan yang mutakhir. Surat tanda bukti sebagai ahli waris dapat berupa Akta Keterangan Hak Mewaris, atau Surat Penetapan Ahli Waris atau Surat Keterangan Ahli Waris.

Keberadaan surat keterangan waris pada pada pendaftaran pendaftaran peralihan hak atas tanah karena pewarisan sangat penting, legalitas daripada pemegang hak yang baru dibuktikan dengan surat keterangan waris tersebut. Pengaturan tentang pembuatan Surat Keterangan 
Ahli Waris bagi golongan Bumiputera termuat dalam Pasal 111 ayat (1) huruf c Peraturan Menteri Agraria / Kepala Badan Pertanahan Nasional Nomor 3 Tahun 1997 sebagaimana dirubah dengan Peraturan Kepala Badan Pertanahan Nasional Nomor 8 Tahun 2012 tentang Ketentuan Pelaksanaan Peraturan Pemerintah Nomor 24 Tahun 1997 tentang Pendaftaran Tanah (selanjutnya disebut sebagai Perkaban No. 8 Tahun 2012), yang menyatakan bahwa surat tanda bukti sebagai ahli waris yang dapat berupa:

1. wasiat dari pewaris, atau

2. putusan Pengadilan, atau

3. penetapan hakim/Ketua Pengadilan, atau

4. bagi warganegara Indonesia penduduk asli: surat keterangan ahli waris yang dibuat oleh para ahli waris dengan disaksikan oleh 2 (dua) orang saksi dan dikuatkan oleh Kepala Desa/ Kelurahan dan Camat tempat tinggal pewaris pada waktu meninggal dunia, bagi warganegara Indonesia keturunan Tionghoa: akta keterangan hak mewaris dari Notaris, bagi warganegara Indonesia keturunan Timur Asing lainnya: surat keterangan waris dari Balai Harta Peninggalan.

5. surat kuasa tertulis dari ahli waris apabila yang mengajukan permohonan pendaftaran peralihan hak bukan ahli waris yang bersangkutan;

6. bukti identitas ahli waris.

Pada pasal tersebut kewenangan Notaris dalam membuat surat keterangan waris dibatasi hanya untuk warga negara Indonesia keturunan Tionghoa, Perbedaan penanganan dalam pembuatan surat keterangan waris berdasarkan pasal tersebut diatas, di latar belakangi oleh ketentuan Perkaban Nomor 3 Tahun 1997 yang masih mengacu pada pasal 163 I.S. yang merupakan aturan warisan jaman penjajahan pemerintah hindia belanda yang menerapkan prinsip penggolongan penduduk. Selain itu, Pasal 111 ayat (1) huruf c Perkaban Nomor 3 Tahun 1997 hanya menjelaskan pembuatan surat keterangan waris yang peruntukannya digunakan sebagai alat bukti ahli waris pada pelaksananaan kegiatan pendaftaran hak atas tanah karena pewarisan.

Pada sub bab sebelumnya diatas sudah dijelaskan bahwa kewenangan pembuatan surat keterangan waris tidak dibatasi oleh ketentuan Pasal 111 ayat (1) huruf c Perkaban Nomor 3 Tahun 1997, maka dalam hal ini Notaris sebagai pejabat umum yang diberi wewenang oleh negara dalam membuat akta otentik memiliki peran yang sangat penting dalam pembuatan surat keterangan waris.

Untuk menganalisis kewenangan Notaris dalam pembuatan surat keterangan waris untuk warga negara Indonesia perlu dianalisis berdasarkan teori kewenangan dengan metode interpretasi sistematis yaitu menafsirkan peraturan perundang-undangan dengan menghubungkan dengan peraturan hukum atau undang-undang lain atau dengan keseluruhan sistem hukum (mertokusumo, 2014).

Berdasarkan teori kewenangan, setiap tindakan pemerintahan dan/atau pejabat umum harus didasarkan pada kewenangan yang sah. Kewenangan itu diperoleh melalui 2 sumber, yaitu atribusi dan pelimpahan.

a. Atribusi adalah wewenang yang diberikan atau ditetapkan untuk jabatan tertentu. Dengan demikian wewenang atribusi merupakan wewenang yang melekat pada suatu jabatan.

b. Pelimpahan dibagi menjadi 2 (dua), yaitu:

1. Delegasi merupakan wewenang yang bersumber dari pelimpahan suatu organ pemerintahan kepada organ lain dengan dasar peraturan perundang-undangan.

2. Mandat merupakan wewenang yang bersumber dari proses atau prosedur pelimpahan dari pejabat atau badan yang lebih tinggi kepada pejabat yang lebih rendah (atasan bawahan).

Jika dianalisis menggunakan interpretasi ekstensif, surat keterangan waris memiliki fungsi yang sangat penting sebagai alat bukti, surat keterangan waris tidak hanya berfungsi dalam kegiatan pertanahan melainkan memiliki fungsifungsi sebagai berikut:

1. Surat keterangan ahli waris memiliki fungsi bagi para ahli waris untuk menggadaikan atau menjaminkan barang-barang harta peninggalan pewaris tersebut kepada pihak lain atau kreditor (Bank);

2. Surat keterangan ahli waris memiliki fungsi untuk mengalihkan barang-barang harta peninggalan pewaris tersebut kepada pihak lain;

3. Surat keterangan ahli waris memiliki fungsi merubah status kepemilikan bersama atas barang harta peninggalan pewaris menjadi milik dari masing-masing ahli waris dengan cara melakukan atau membuat akta pembagian dan pemisahan harta peninggalan pewaris dihadapan Notaris; 
4. Surat keterangan ahli waris memiliki fungsi sebagai alat bukti bagi ahli waris untuk dapat mengambil atau menarik uang dari pewaris yang ada pada suatu bank atau asuransi.

Mengingat keberadaan surat keterangan waris sangat penting, perlu dibuat dalam bentuk yang ditetapkan oleh Undang-Undang (otentik) agar memiliki kekuatan hukum yang sempurna. Maka berdasarkan metode interpretasi sistematis, dalam hal ini surat keterangan waris yang dibuat dalam bentuk akta otentik memenuhi ketentuan Pasal 1870 KUHPerdata yang menjelaskan :

Bagi para pihak yang berkepentingan beserta para ahli warisnya ataupun bagi orang-orang yang mendapatkan hak dari mereka, suatu akta otentik memberikan suatu bukti yang sempurna tentang apa yang termuat di dalamnya.

Menurut Pasal 1870 KUHPerdata bahwa suatu akta otentik memberikan suatu bukti yang sempurna tentang apa yang termuat di dalamnya, dalam hal kaitanya dengan ahli waris dalam surat keterangan warisnya dibuat dalam bentuk otentik. Selanjutnya dihubungkan mengenai akta otentik dalam Pasal 1868 KUHPerdata menyebutkan:

Suatu akta otentik adalah suatu akta yang dibuat dalam bentuk yang ditentukan oleh undang-undang oleh atau dihadapan pejabat umum yang berwenang unuk itu di tempat akta itu dibuat.

Maksud dari pasal 1868 KUHPerdata mengandung 3 unsur, yaitu: 1) Di dalam bentuk yang ditentukan oleh Undang-Undang. 2) Dibuat oleh dan di hadapan pejabat umum. 3) Akta yang dibuat oleh atau di hadapan pejabat umum yang berwenang untuk dan di tempat dimana ata itu dibuat.

Salah satu unsur yaitu dibuat oleh dan dihadapan pejabat umum yang merupakan Notaris, dalam Pasal 1 UUJN menyebutkan "Notaris adalah pejabat umum yang berwenang untuk membuat akta otentik dan kewenangan lainnya sebagaimana dimaksud dalam Undang-Undang ini" mengenai kewenangan Notaris tersebut diatur dalam Pasal 15 UUJN yang menyebutkan:

Ayat 1:

Notaris berwenang membuat akta otentik mengenai semua perbuatan, perjanjian, dan ketetapan yang diharuskan oleh peraturan perundangundangan dan/atau yang dikehendaki oleh yang berkepentingan untuk dinyatakan dalam akta otentik, menjamin kepastian tanggal pembuatan akta, menyimpan akta, memberikan grosse, salinan dan kutipan akta, semuanya itu sepanjang pembuatan akta-akta itu tidak juga ditugaskan atau dikecualikan kepada pejabat lain atau orang lain yang ditetapkan oleh undang-undang.

Pada ayat (2) dijelaskan kewenangan Notaris selain yang dimaksud pada ayat (1) yaitu: (a) mengesahkan tanda tangan dan menetapkan kepastian tanggal surat di bawah tangan dengan mendaftar dalam buku khusus; (b) membukukan surat di bawah tangan dengan mendaftarkan dalam buku khusus; (c) membuat copy dari asli surat di bawah tangan berupa salinan yang memuat uraian sebagaimana ditulis dan di gambarkan dalam surat yang bersangkutan; (d) melakukan pengesahan kecocokan fotocopy dengan surat aslinya; (e) memberikan Penyuluhan hukum sehubungan dengan pembuatan akta; (f) membuat akta yang berkaitan dengan pertanahan; atau (g) membuat akta risalah lelang.

Kewenangan Notaris yang akan ditentukan kemudian terdapat dalam ayat (3) menyebutkan, Selain kewenangan sebagaimana dimaksud pada ayat (1) dan ayat (2), Notaris mempunyai kewenangan lain yang diatur dalam peraturan perundang-undangan. Melalui hubungan antara keseluruhan peraturan-peraturan yang diuraikan secara sistematis maka kewenangan Notaris dalam pembuatan surat keterangan waris dalam bentuk akta otentik merupakan kewenangan atribusi yang merupakan merupakan pemberian wewenang yang baru kepada suatu jabatan berdasarkan suatu peraturan perundang-undangan atau aturan hukum. Melalui teori kewenangan atribusi ini Notaris memperoleh sumber kewenangan dari Pasal 15 Undang-Undang Nomor 2 Tahun 2014 tentang Perubahan Atas Undang-Undang Nomor 30 Tahun 2004 tentang Peraturan Jabatan Notaris (UUJN).

Dasar hukum tersebut dapat dijadikan dasar pembuatan surat keterangan waris. Sehingga atas dasar hukum tersebut Notaris dapat menciptakan bentuk surat keterangan waris/akta keterangan hak mewaris yang diberlakukan bagi seluruh 
bangsa Indonesia yang membutuhkannya tanpa lagi didasarkan pada dasar hukum Belanda dengan prinsip pembedaan atau penggolongan penduduk.

Selain penjelasan diatas, Pasal 111 ayat (1) huruf cPerkaban Nomor 3 Tahun 1997 juga menjelaskan bahwa surat keterangan waris untuk warga negara Indonesia yang digolongkan ke dalam golongan pribumi dibuat oleh para ahli waris sendiri dengan disaksikan oleh 2 (dua) orang saksi dan diketahui maupun dikuatkan oleh kepala desa/ kelurahan serta camat tempat tinggal pewaris pada waktu meninggal dunia dan surat keterangan waris bagi warga negara Indonesia keturunan timur asing dibuat oleh balai harta peninggalan.

Kewenangan camat dalam pembuatan surat keterangan waris tidak diatur dalam UndangUndang Nomor 32 Tahun 2004 sebagaimana diubah dengan Undang-Undang Nomor 23 Tahun 2014 tentang Pemerintahan Daerah, tidak dapat ditemukan ayat yang menyebutkan secara rinci mengenai wewenang kepala desa, lurah dan camat untuk mengetahui ataupun menguatkan surat keterangan waris yang dibuat oleh ahli waris yang termasuk golongan pribumi. Sehingga kepala desa, lurah dan camat tidak memiliki kewenangan untuk menyaksikan dan menguatkan surat keterangan waris karena suatu kewenangan haruslah bersumber dari suatu peraturan perundangundangan baik diperoleh dengan cara atribusi, delegasi ataupun mandat. Sesuai dengan pendapat dari R.J.H.M. Huisman (2006), yang menjelaskan bahwa kewenangan hanya dapat diberikan oleh undang-undang.

Balai harta peninggalan (BHP) merupakan bagian dari struktur organisasi Departemen Hukum dan Hak Asasi Manusia, dibawah lingkungan Direktorat Perdata. Menurut I Gede Purwaka (1999), secara struktural tersebut maka BHP merupakan lembaga pemerintahan (eksekutif) yang melaksanakan urusan pemerintah.Kewenangan BHP dalam membuat surat keterangan waris merujuk pada Pasal 111 ayat (1) huruf c Perkaban Nomor 3 Tahun 1997 yang merupakan petunjuk membuat surat keterangan waris untuk digunakan sebagai alat bukti ahli waris pelaksanaan pendaftaran tanah karena pewarisan saja, dengan kata lain BHP tidak memiliki kewenangan untuk membuat surat keterangan waris yang peruntukannya diluar dari pelaksanaan pendaftaran tanah karena pewarisan.

Selain hal diatas, Pasal 111 ayat (1) huruf c Perkaban Nomor 3 Tahun 1997 juga menyatakan surat tanda bukti sebagai ahli waris dapat berupa penetapan Hakim/Ketua Pengadilan. Mereka yang tunduk kepada hukum adat dan orang-orang Kristen, Surat Keterangan Waris dibuat oleh Pengadilan Negeri di tempat tinggal terakhir pewaris. Untuk mereka yang tunduk pada hukum Islam, Surat Keterangan Mewaris dibuat oleh Pengadilan Agama (Syari'ah). Namun, Pada saat ini Pengadilan Negeri dan Pengadilan Agama sudah tidak berwenang lagi membuat Surat Keterangan Waris. Hal tersebut dinyatakan dengan Surat Ketua Muda Mahkamah Agung tertanggal 8 Juli 1993 Nomor:26/TUADA-AG/IIIUM/VII/1993 (Purwaka, 1999).

Saat ini Pengadilan Negeri dan Pengadilan Agama hanya berwenang untuk mengeluarkan Putusan untuk menetapkan ahli waris jika di antara para ahli waris atau dalam pewarisan tersebut terhadi sengketa yang diajukan ke pengadilan. Demikian juga permohonan untuk menetapkan seseorang atau beberapa orang adalah ahli waris dari almarhum, tidak dapat diajukan. Penetapan ahli waris dapat dikabulkan dalam suatu gugatan mengenai ahli waris almarhum (MA, 2003).

Berdasarkan penjelasan diatas, dari keempat institusi yang diberikan kewenangan untuk membuat surat keterangan waris, dapat dilihat bahwa Notarislah yang sebenarnya paling tepat untuk membuat surat keterangan waris dari segi institusinya. Karena Notaris sebagai pejabat umum diberikan kewenangan untuk melaksanakan sebagian tugas negara dalam membuat alat bukti otentik dibidang hukum perdata yang kewenangannya diatur dalam peraturan tersendiri.

Kekuatan Hukum Surat Keterangan Waris yang Dibuat Oleh Notaris Berdasarkan UndangUndang Nomor 24 Tahun 2013 Tentang Administrasi Kependudukan Ditinjau dari Teori Kepastian Hukum

Berdasarkan perspektif Pasal 106 UndangUndang Nomor 23 Tahun 2006 Sebagaimana Diubah Dengan Undang-Undang Nomor 24 Tahun 2013 Tentang Administrasi Kependudukan, Notaris memiliki wewenang untuk membuat surat keterangan waris tanpa memperhatikan penggolongan penduduk. Kewenangan Notaris dalam pembuatan surat keterangan waris untuk warga negara Indonesia didasarkan pada ketentuan Pasal 15 UUJN, sehingga surat keterangan waris untuk warga negara Indonesia dibuat dalam bentuk akta otentik. Untuk menguji 
apakah surat keterangan hak mewaris yang dibuat oleh Notaris merupakan akta otentik maka perlu ditinjau dari Teori Kepastian hukum melalui pendekatan analitis.

Kepastian merupakan ciri yang tidak dapat dipisahkan dari hukum, terutama untuk norma hukum tertulis. Hukum tanpa nilai kepastian akan kehilangan makna karena tidak dapat lagi digunakan sebagai pedoman perilaku bagi setiap orang. Kepastian sendiri disebut sebagai salah satu tujuan dari hukum. Peringkat analisis yang fundamental untuk menentukan baik buruknya aturan hukum atau sistem hukum adalah peringkat analisis moral. Lon Fuller membedakan muatan moral pada dua aspek, yakni aspek internal dan aspek eksternal (Sidharta, 2008).

Lon Fuller mengemukakan delapan asas sebagai landasan dan syarat-syarat legitimasi bagi implementasi asas legalitas (kepastian hukum), yaitu: (a) hukum dipresentasikan dalam aturan-aturan umum; (b) hukum harus dipublikasi; (c) hukum harus non retroaktif (tidak berlaku surut); (d) hukum harus dirumuskan secara jelas; (e) hukum harus tidak mengandung pertentangan antara hukum yang satu dengan yang lain; (f) hukum harus tidak menuntut atau mewajibkan sesuatu yang mustahil; (g) hukum harus relatif konstan; (h) pemerintah sejauh mungkin berpegang teguh pada aturan-aturan hukum (yang diciptakan sendiri atau yang diakuinya).

Untuk mengetahui kesesuaian delapan asas kepastian hukum diatas mengenai kekuatan hukum surat keterangan waris yang dibuat oleh Notaris, maka harus diukur berdasarkan ketentuanketentuan yang mengatur mengenai legalitas produk hukum yang dihasilkan oleh Notaris yang dalam hal ini adalah akta otentik. Untuk mengukur kekuatan hukum surat keterangan waris sebagai akta otentik, maka surat keterangan waris harus memenuhi unsur-unsur mengenai akta otentik. Menurut Iwan Soedirjo, terdapat tiga unsur esensilia agar terpenuhinya syarat formal suatu akta otentik, yaitu dibuat dalam bentuk ditentukan oleh UndangUndang, dibuat oleh atau dihadapan pejabat umum yang berwenang, dan akta yang dibuat oleh atau dihadapan pejabat umum yang berwenang untuk itu dan tempat dimana akta tersebut dibuat. Wewenang Notaris untuk membuat akta dalam bentuk yang otentik diatur lebih lanjut pada ketentuan pasal 1868 KUHPerdata yaitu:

Suatu akta otentik adalah suatu akta yang dibuat dalam bentuk yang ditentukan oleh undang-undang oleh atau dihadapan pejabat umum yang berwenang unuk itu di tempat akta itu dibuat.

Ketentuan dalam pasal 1868 KUHPerdata tersebut suatu akta dapat dikatakan sebagai akta otentik apabila memenuhi syarat-syarat sebagai berikut:

1. Akta tersebut dibuat oleh (door) atau dibuat dihadapan (tenoverstaan), seorang pejabat umum (openbareambtenaren)

2. Akta tersebut harus dibuat dalam bentuk (vorm) yang telah ditentukan oleh UndangUndang (wettelikjevorm).

3. Pejabat umum yang membuat akta harus mempunyai kewenangan untuk membuat akta tersebut, baik kewenangan berdasarkan daerah/wilayah kerjanya atau waktu pada saat akta tersebut dibuat.

Akta otentik menurut F. Eka Sumarningsih (2001) dibagi menjadi dua yaitu partij acta dan relaas acta.Akta partij atau akta pihak adalah akta yang dibuat dihadapan Notaris, artinya akta yang dibuat berdasarkan keterangan atau perbuatan pihak yang menghadap Notaris, dan keterangan atau perbuatan itu agar dikonstantier oleh Notaris untuk dibuatkan akta. Sedangkan akta relaas atau akta pejabat adalah akta yang dibuat oleh Notaris sebagai pejabat umum yang memuat uraian secara otentik tentang semua peristiwa atau kejadian yang dilihat, dialami, dan disaksikan oleh Notaris sendiri.

Akta otentik mempunyai kekuatan atau nilai pembuktian secara garis besarnya diuraikan sebagai berikut:

1. Lahiriah. Kemampuan akta itu sendiri untuk membuktikan keabsahannya sebagai akta otentik. Jika dilihat dari luar (lahirnya) sebagai akta otentik serta sesuai dengan aturan hukum yang sudah ditentukan mengenai syarat akta otentik, maka akta tersebut berlaku sebagai akta otentik, sampai terbukti sebaliknya, artinya sampai ada yang membuktikan bahwa akta tersebut bukan akta otentik secara lahiriah.

2. Formal. Harus memberikan kepastian bahwa sesuatu kejadian dan fakta tersebut dalam akta betul-betul dilakukan oleh pejabat umum atau diterangkan oleh pihak-pihak yang menghadap pada saat yang tercantum dalam akta sesuai dengan prosedur yang sudah ditentukan dalam pembuatan akta. 
3. Materiil. Kepastian tentang misteri suatu akta, keterangan atau pernyataan yang dituangkan /dimuat dalam akta harus dinilai benar.

Pertama, syarat akta dbuat oleh (door) atau dibuat dihadapan (ten overstain) pejabat umum yang ditunjuk oleh Undang-Undang berdasarkan Undang-Undang Nomor 2 Tahun 2014 tentang Perubahan Atas Undang-Undang Nomor 30 Tahun 2004 tentang Peraturan Jabatan Notaris. Dalam Pasal 1 ayat (1) disebutkan bahwa "Notaris adalah pejabat umum yang berwenang untuk membuat akta otentik dan kewenangan lainnya sebagaimana dimaksud dalam undang-undang ini.

Pejabat umum disini diartikan sebagai pejabat yang diserahi tugas untuk membuat akta otentik yang melayani kepentingan publik. Dari ketentuan tersebut terlihat bahwa kualifikasi Notaris sebagai pejabat umum terpenuhi karena diatur secara khusus dalam suatu Undang-Undang tersendiri. Pemberian kualifikasi Notaris sebagai pejabat umum berkaitan dengan wewenang Notaris, menurut ketentuan Pasal 15 ayat (1) Undang-Undang Nomor 2 Tahun 2014 tentang Perubahan Atas Undang-Undang Nomor 30 Tahun 2004 tentang Peraturan Jabatan Notaris bahwa Notaris berwenang membuat akta otentik, sepanjang pembuatan akta-akta tersebut tidak digunakan atau dikecualikan kepada pejabat atau orang lain.

Dengan demikian pejabat umum merupakan suatu jabatan yang diberikan kepada mereka yang diberi wewenang oleh aturan hukum dalam pembuatan akta otentik, dan Notaris sebagai pejabat umum kepadanya diberikan kewenangan untuk membuat akta otentik. Sehingga dalam hal ini memenuhi syarat yang ditentukan oleh Pasal 1868 KUHPerdata.

Kedua, bentuk (vorm) akta yang dibuat oleh pejabat umum yang dikatakan sebagai akta otentik, harus ditentukan oleh undang-Undang. Terhadap akta keterangan hak mewaris yang selama ini dibuat oleh Notaris, bentuknya tidak pernah diatur dengan Undang-Undang. Bentuk akta keterangan hak mewaris yang dibuat oleh Notaris hanya diatur dalam Pasal 111 ayat (1) huruf c angka 4 peraturan Menteri Negara Agraria/Kepala Badan Pertanahan Nasional Nomor 3 Tahun 1997 tentang Ketentuan Pelaksanaan Peraturan Pemerintah Nomor 24 Tahun 1997 tentang Pendaftaran Tanah dalam bentuk akta namun masih terdapat perbedaan pendapat mengenai bentuk dari akta keterangan waris harus dibuat seperti apa.
Ketiga, pejabat umum yang membuat akta harus mempunyai kewenangan untuk membuat akta tersebut, baik kewenangan berdasarkan daerah/wilayah kerjanya atau waktu pada saat akta tersebut dibuat. Wewenang Notaris menurut Tobing (1983) meliputi empat hal, yaitu: (1) Notaris harus berwenang sepanjang yang menyangkut akta yang dibuatnya itu, (2) Notaris harus berwenang sepanjang mengenai orang-orang, untuk kepentingan siapa akta itu dibuat, (3) Notaris harus berwenang sepanjang mengenai tempat, dimana akta itu dibuat, dan (4) Notaris harus berwenang sepanjang mengenai pembuatan akta itu.

Menurut Sudikno Mertukusumo (1993) Suatu akta yang dibuat oleh pejabat tanpa ada wewenang dan tanpa ada kemampuan untuk membuatnya atau tidak memenuhi syarat, maka tidaklah dianggap sebagai akta otentik, tetapi hanya mempunyai kekuatan sebagai akta dibawah tangan apabila ditandatangani oleh pihak-pihak yang bersangkutan.

Pasal 15 Undang-Undang Nomor 2 Tahun 2014 tentang Perubahan Atas Undang-Undang Nomor 30 Tahun 2004 tentang Peraturan Jabatan Notaris menentukan wewenang Notaris, wewenang ini merupakan suatu batasan bahwa Notaris tidak boleh melakukan suatu tindakan diluar wewenang tersebut. Kewenangan Notaris dalam pembuatan surat keterangan waris merupakan bentuk pelaksanaan Notaris sebagai pejabat umum yang berwenang dalam pembuatan alat bukti otentik. Kewenangan Notaris dalam pembuatan surat keterangan waris hanya diatur dalam ketentuan Pasal 111 ayat (1) huruf c angka 4 peraturan Menteri Negara Agraria/Kepala Badan Pertanahan Nasional Nomor 3 Tahun 1997 tentang Ketentuan Pelaksanaan Peraturan Pemerintah Nomor 24 Tahun 1997 tentang Pendaftaran Tanah.

Dengan demikian, maka surat keterangan waris yang dibuat oleh Notaris merupakan akta otentik yang berdasarkan Pasal 1868 KUHPerdata. Dari segi pembuktian akta keterangan waris dalam bentuk akta otentik mempunyai nilai pembuktian yang sempurna karena dibuat dihadapan pejabat yang berwenang yaitu Notaris (Yuriz, 2016).

Surat keterangan waris dalam bentuk akta otentik memberikan suatu bukti yang sempurna tentang apa yang termuat di dalamnya, sejauh surat keterangan waris tersebut masih dapat dipakai, dan kesepakatan yang terdapat 
didalamnya belum berakhir, maka sekalipun para pihak telah meninggal, para ahli warisnya tetap harus dan wajib memenuhi segala ketentuan yang tertuang di dalam surat keterangan waris tersebut, namun apabila kebenaran dalam akta otentik dibantah maka pihak yang membantah harus membuktikan ketidakbenaran dari surat keterangan waris tersebut.

\section{SIMPULAN}

1. Kewenangan notaris mengenai pembuatan surat keterangan waris untuk warga negara Indonesia dalam perspektif Pasal 106 UndangUndang Nomor 23 Tahun 2006 Sebagaimana Diubah dengan Undang-Undang Nomor 24 Tahun 2013 Tentang Administrasi Kependudukan adalah sah demi hukum, berdasarkan teori hierarki peraturan perundang-undangan, prinsip penggolongan penduduk yang masih terdapat pada ketentuan Pasal 111 ayat (1) huruf c Peraturan Menteri Agraria / Kepala Badan Pertanahan Nasional Nomor 3 Tahun 1997 sebagaimana dirubah dengan Peraturan Kepala Badan Pertanahan Nasional Nomor 8 Tahun 2012 tentang Ketentuan Pelaksanaan Peraturan Pemerintah No. 24 Tahun 1997 tentang Pendaftaran Tanah dikesampingkan, sehingga tidak membatasi kewenangan Notaris dalam pembuatan surat

\section{DAFTAR RUJUKAN}

Hartono, Sunarjati. 1991. Dari Hukum Antar Golongan ke Hukum Antar Adat, Bandung: Citra Aditya Bakti

Harun, Arsyad. 2010. Tinjauan Yuridis Surat Keterangan Hak Waris bagi Penduduk di Indonesia, Bandung: Refika Aditama

Kie, Tant Tong. 2007. Studi Notariat \& SerbaSerbi Praktek Notaris, Jakarta: Ichtiar Baru van Hoeve

Mertokusumo, Sudikno. 2014. Penemuan Hukum Sebuah Pengantar, Edisi Revisi, Yogyakarta: Cahaya Atma Pustaka

Nurjaya, I Nyoman. 2008. Pengelolaan Sumber Daya Alam dalam Perspektif Antropologi Hukum, Jakarta: Prestasi Pustaka Publisher

Purwaka, I Gede. 1999. Keterangan Hak Mewaris yang dibuat oleh Notaris, Jakarta: Universitas Indonesia keterangan waris untuk warga negara Indonesia. Berdasarkan teori kewenangan, kewenangan Notaris dalam membuat surat keterangan waris untuk warga negara Indonesia merupakan kewenangan atribusi yang sumber kewenangannya berdasarkan Pasal 15 ayat (1) Undang-Undang Nomor 2 Tahun 2014 tentang Perubahan Atas Undang-Undang Nomor 30 Tahun 2004 tentang Peraturan Jabatan Notaris.

2. Kekuatan hukum surat keterangan waris untuk warga negara Indonesia yang dibuat oleh Notaris memiliki kekuatan pembuktian yang sempurna. Berdasarkan teori kepastian hukum, surat keterangan waris yang dibuat oleh Notaris merupakan akta otentik yang berdasarkan Pasal 1868 KUHPerdata. Surat keterangan waris dalam bentuk akta otentik memberikan suatu bukti yang sempurna tentang apa yang termuat di dalamnya, sejauh masih dapat dipakai, dan kesepakatan yang terdapat didalamnya belum berakhir. Maka sekalipun para pihak telah meninggal, para ahli warisnya tetap harus dan wajib memenuhi segala ketentuan yang tertuang di dalam akta tersebut, namun apabila kebenaran dalam surat keterangan waris tersebut dibantah, maka pihak yang membantah harus membuktikan ketidakbenaran dari surat keterangan waris tersebut.

Sidharta, Arief. 2008. Ethika Hukum, Bandung: Laboratorium Hukum Fakultas Hukum Universitas Katolik Parahyangan

Tobing, G.H.SLumban. 1983. Peraturan Jabatan Notaris, Jakarta : Erlangga

\section{Peraturan Perundang-undangan:}

Peraturan Kepala Badan Pertanahan Nasional No. 8 Tahun 2012 tentang Ketentuan Pelaksanaan Peraturan Pemerintah No. 24 Tahun 1997 tentang Pendaftaran Tanah. Peraturan Pemerintah No. 24 Tahun 1997 tentang Pendaftaran Tanah.

Peraturan Kepala Badan Pertanahan Nasional No. 8 Tahun 2012 tentang Ketentuan Pelaksanaan Peraturan Pemerintah No. 24 Tahun 1997 tentang Pendaftaran Tanah. 
Undang-Undang Nomor 2 Tahun 2014 Tentang

Perubahan Undang-Undang Nomor 30

Tahun 2004 Tentang Jabatan Notaris.
Undang-Undang Nomor 32 Tahun 2004 Sebagaimana Diubah Dengan Undang Undang Nomor 23 Tahun 2014 Tentang Pemerintahan Daerah 